\title{
ISLAMIC RELIGIOUS VALUES REPRESENTED BY MAIN CHARACTERS AND PORTRAYED OF ISLAM WITHIN BUMI CINTA
}

\author{
${ }^{1}$ Wiwiek Afifah \\ Email : ${ }^{1}$ wiwiekafifah.2018@student.uny.ac.id \\ Yogyakarta State University
}

ABSTRACT

Article history

Received

Revised

Accepted

Keywords

Islam

Values

Bumi Cinta
Negative perceptions toward Islam are increasing because of the emergence of various issues in intolerance. On the other hand, an Islamic novel entitled Bumi Cinta is full of virtuous capturing from the representation of the main character. Therefore, this study aims to find out the religious values and Islamic representations. The research method is inferential content analysis with the data obtained from the novel. The data procurement includes sampling and determination of the unit then validity of data is done by discussing them to the experts. The technique to analyze the data is classification, making meaning, and inference. Findings of this study are the spirit of seeking knowledge, honesty, discipline in worship, carry out all the religions commands, never surrender when getting problems, patient when facing temptations, stay away from haram foods, sincere in giving aids, establishing fraternal relations with friends across religions and appeal to do good things. Therefore, from the whole analysis, it can be stated that Islam is a peaceful and tolerance religion that drove its adherents to become good people.

This is an open access article under the $\mathrm{CC}-\mathrm{BY}-\mathrm{SA}$ license

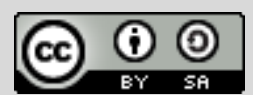

\section{INTRODUCTION}

Negative perceptions toward Islam are increasing due to the emergence of various issues in intolerance occurring in the midst of society (Fenton 2016; Meer and Modood 2009). The issue that Islam is a conservative religion also has made the world's population increasingly antipathetic to Islam. There are some evidences which can be traced that not all people can accept and welcome Islam conversely, they ignore and conspire against Islam believers. Even, several months ago, 50 Muslim worshippers were shot dead by an attacker on Friday at two mosques (Jazeera, 2019). There are some reasons behind that attack. At the heart of the matter, cynicism, perception that Islam is resistant to change, very old-fashion and identical as a terrorist obviously appear from them. The condition becomes even worse when Islam conservative and Muslim extremists are frequently appeared in some mass media. Therefore, it cannot be denied that conspiration got across Muslim are stronger in the world community. Many anti-Islamic movements then are carried out so that Islam was ostracized and abandoned (Zainiyati 2016). Essentially, in this part of the world, a lot of people still considered that Islam is a radical, intolerant and must be vanished (Thomas 2015).

Yet, Islam is a peaceful religion indeed (Foster 2016; Valk and Selçuk 2017) and many good values are explicitly described in Al Qur'an. Islam comes to this world for helping and making human being to have physically and mentally prosperous (Muslim 2017; Umer Chapra 


MIMESIS
Und. 2. No. 1, Januari 2021
Universitas
Ahmad Dahlan

2016). Then attempting in stopping the problems of negative perception toward Islam, a novel entitled Bumi Cinta can be used as one of the mediums to solve those troubles. It is because inside the novel, there are several examples on how Islam is represented. Add to this, the author of the novel can intelligently and smoothly portrayed Islam through the characters' representation in handling the problem based on Islam's tenets in some real-life contexts.

Furthermore, scholars also declared that a novel as one of the literary works can be used as one of the alternative ways to give evidence that Islam is not wrong religion. Islam is a blessed religion for all people around this world. Additionally, it is due to the fact that a novel contains some of the important things relating to deep reflection at the time when the author wrote the story inside it (Johns 2011). As the reflection of the reality, it must cover some realistic problems happened in daily life in which they can be used as the life guidance. Additionally, it is a fact that there are several conflicts happen around the world in which the author can capture and transfer those realities into his or her masterpiece.

In terms of literary artwork, sometimes the author also wanted to capture the reality that he or she meets through the existence of the character in the story. Bennett and Royle (2004) explained that characters are the life of literature in which they are the objects of their curiosity and fascination, affection and dislike, admiration and condemnation. Characters of the novel have significant functions. Add to this, they name the character as the 'real' people. Thus, those are very critical to analyze (p. 62). Turning to, people or readers can achieve the moral as well as the messages conducted and served by the author from the novel they read.

Islamic novel entitled Bumi Cinta is controlled by the existence of the main characters: Muhammad Ayyas, Yelena, and Linor. As the young Muslim, he is portrayed as a perfect young Muslim who's a high motivation to be a good academic researcher as well as to be a good Muslim. Thus, the plot of the story is dominated by his struggle in gathering all the data he needed in the research and the way to overcome the entirely problems coming from his two friends; Yelena and Linor. On his ongoing process in finding the empirical data of the research, he meets many obstacles that are dealt with the temptation on sequences of excitements. Naturally, he must against them. Concisely, Islamic values in the real life are perfectly portrayed through the main character in that story. Yet, Yelena and Linor the other ones who are the main characters who also support the story. Through their existence, Islam is beautifully depicted by the author.

Based on the view, this study attempts to reveal the religious values represented by the main characters. This novel had been investigated by some previous researchers, such as Hassan and Hun (2018) who do their study about comparing the concept of creation between Islamic elements and romantic love in Indonesia and Malaysia, Koh (2014) who used model rhetoric's dakwah al-hikmah to investigated the novel, and Mubin (2014) who also investigates the elements of religiosity. Yet, this study is different. It is still salient to do for investigating how the main character deals with problems. Therefore, this investigation is still important to do for some reasons. Such as the novel still heave been read by almost people of all ages in Indonesia. The novel still can attract and change people' mind to do the same things as the main character did. Secondly, the quantity of people being conspired of Islam as an anarchy 


MIMESIS
Und. 2. No. 1, Januari 2021
Universitas
Ahmad Dahlan

religion have increased. Some conflicts happen around the world in which they are alerted by the discrepancy of comprehending Islam have raised. Thirdly, the novel' author could serve a number of conflicts which lead to the perfect of multi-culminations. Furthermore, the setting of the entirely stories also can bring readers to the real world of their imagination in those places. Even, as the readers increase, this novel is released into a film.

Considering the purpose of this study, the research method applied is a content analysis with formal and critical analysis trying to reveal the religious values. The underlying reasons why formal and critical analysis are applied are: they enable to help the researcher to find out what are structural content, give signs of the religious values behind the story, and help in dig out the author's thinking. This investigation is believed to give positive contribution on how to understand Islam. It is in line to the effort for avoiding the emerging stereotype in seeing Islam as an extreme ideology.

Having done analyzed these Islamic religious values from the novel, it is expected to give some positive contributions to the global readers in order they will understand Islam. In line with the idea, it is also important to discuss and to understand that Islam in a global context since this religion also teaches us how to be good human beings. To be good human should be concerned with religion (Blackburn 2007). Consequently, the two research questions that lead this current study are (a) what are the Islamic religious values that are represented by the main characters and (b) how the author portrayed Islam through the existence of the main characters in that story.

\section{METHOD}

The design of the research is an inferential content analysis (Krippendorff 2018). As a part of a qualitative approach, the researcher takes the main data from the novel Bumi Cinta. An analytical analysis is done to find out and to describe the religious values represented by the main character and to judge the dominant ideology infiltrating within story. Research procedure encompasses the following points; data record-keeping, determining units, determining samples, data reduction, inferential, and analysis.

The research instruments used in this inferential content analysis is the researcher herself. It is also called as the human instrument. While the techniques applied to gain the data are by writing the entirely of religious values represented by the main character. The collected data then are analyzed qualitatively in which the researcher attempts to find the meaning and described the whole religious values represented by the main character. After that, what the researcher does is judging the dominant ideology infiltrating the story and making a conclusion of Islamic representation.

The procedure in analyzing the data are (1) classifying data based on its family, and (2) finding their meaning after they have been classified. On the phase, the researcher attempts to gain the religious values particularly what have been stated and taught in Islam. Finding the meaning which is based on the analytic construct and determined based on the inference steps. They cover identification, grouping based on the Islamic values, and judging the Islamic 
representation infiltrating within story. The data analysis is closed by making any judgments of the novel.

\section{DISCUSSION}

Data are collected to answer the following questions. They are to find out what are Islamic religious values that are represented by the main characters and how the author portrayed Islam through the existence of the main characters.

\section{Data Description of Islamic Religious Values}

The novel entitled Bumi Cinta was written by an Indonesian novelist names Habiburrahman El Shirazy. It was published by Pondok Pesantren Basmala (546 pages) and consists of some chapters in which they have different themes and conflicts. There are forty chapters within the novel in which they are written in Bahasa Indonesia. Although this novel was published in 2013, the story is still up to date. Even, the conflicts are still happening in this year.

Habiburrahman El Shirazy drew the plot Bumi Cinta with a progressive dramatic style. He chronologically structured and established the setting and conflict which were followed by some rising actions to a climax or the peak of the action and turning point. The way he expressed the plot and sequences of actions were similar to what Dallas (2000) and Lortie (1999) did. The entirely story told about Ayyas's struggles in undergoing his life when pursuing the data of his research. Unfortunately, a few conflicts came across him as he was struggling for getting the data.

There were three main characters in the story. They were Ayyas, Yelena, and Linor. They lived in the same apartment and the conflicts were dominantly about three of those characters. The conflicts were mostly about the flaming souls of the two women who missed the real happiness. Then, when Yelena and Linor were on their seventh heaven, they started realizing about the other side of their life. There was something that they felt different but did not know the answer. They could not understand and hard to find the answer. That was about no rose without a thorn. They had their cheeriness and they seemed happy but no rose without a thorn. They got a bad fall while they were in their absolute liberty.

The beginning of the novel was started by the arrival Ayyas in Moskwa. As he had to gain the primary data of his research, he must observe, interview and did consultation to some experts living in Russia. With the help of David, his close friend who studied in Russia, Ayyas stayed with two beautiful and charming women who's different lifestyle. The problems started when Ayyas found that one of the girls, Yelena was an atheist. Furthermore, he also felt that Linor, the other girl who lived in that apartment was conceited and arrogant. Sometimes, Yelena admitted conceitedly that she didn't believe in God. Knowing that fact, Ayyas was involved his mind to the reality. He was angry at the Yelena's principle and tried hard to bring her in the right way.

Islamic religiosities reflected by the main character in the novel are (1) having a good spirit in pursuing knowledge, (2) having a good manner as well as discipline in doing the worship or Islamic tenets, (3) trying hard to avoid the religious prohibitions and performing 


MIMESIS
Und. 2. No. 1, Januari 2021
Universitas
Ahmad Dahlan

the religious obligation or avoiding the haram, behavior that is forbidden and carry out the halal or behavior that is permitted by Islam. In addition, Ayyas, as the flat character and as the protagonist (4) show his gentle by always remembering Allah wherever and whenever he is. (5) Having a good habit such as love reading, discussing, teaching good things, (6) patient and calm whenever he faces the problems.

The Islamic representations through the main character of Ayyas are categorized into three aspects. They are religious values that deal with: a) how to keep a good relationship between human being or the servant of Allah with Allah as the only creator, b) how to make a good relationship between human beings or the servant of Allah with the other human beings, and c) how to maintain the relationship between nature and all entirely with himself.

Striving for science and knowledge enthusiastically is the prominent aspect of the story. Even the story rose when the main character came to Moscow for completing his research. His long journey and very strained condition were started when his research consultant demanded him to gain the primary data in the Russian community. That demand was prosecuted so Ayyas had to come to the community whose different faith with him.

As a good Muslim, Ayyas showed his good manner as well as his discipline in doing the worship. He tried hard to be on time for praying to Allah for five times. Discipline in doing the worship was clearly shown in some chapters of the novel. As an addition, Ayyas was also trying hard to avoid the religious prohibitions and performing the religious obligation such as: never make a direct contact with females such as looking at the women passionately, looking for any chances to make conversation and so on. Ayyas as the main character of the novel showed some good attitudes as guided by Islamic doctrines. The other of good examples reflected by Ayyas are he tried hard to avoid the haram, behavior that is forbidden and to carry out the halal or behavior that is permitted by Islam. The following quotation is the proof that Ayyas is a good Muslim who always keeps his faith.

"Ya Allah rahmatilah hamba-Mu ini dengan meninggalkan maksiat selamanya, ...." (ElZirazy, 2013, p. 68).

The quotation shows that Ayyas is a good man who is always in guard. He directly did the pray and started remembering Allah while he asked help from his creator. When feeling that he was in a bad condition, he also asked for help from Allah. The following is a quotation.

"Ya Allah hamba minta kepada-Mu kebaikan daerah ini, kebaikan penghuninya dan kebaikan yang ada di dalamnya...." (El-Zirazy, 2013, p. 69).

From that quotation, it can be understood that as a traveler, a student, and a researcher, Muhammad Ayyas always hopes for the best and good things in his life. On the other hand, the desire to avoid the bad things in his life, he always actualized their will by reading Al-Qur'an and begging Allah to protect his life wherever and whenever he was. As an addition, in order to be a good Muslim, he also protect his mind by avoiding some bad things such as bragging, teasing, deceiving, and other activities that can make him fall into a trap. Let's take a look for the following quotation. 


MIMESIS
Und. 2. No. 1, Januari 2021
Universitas
Ahmad Dahlan

“Ayyas diam membisu. Ia menata hati dan pikirannya ...” (El-Zirazy, 2013, p.85).

“Ayyas terpaksa keluar dari kamarnya dan makan bersama Yelena di ruang tamu”... (El-Zirazy, 2013, p. 86).

As Ayyas had to live with two women in one apartment, he always found himself in trouble. Yelena always asked him to get dinner together, make a conversation for only to spend the day, and some other activities that can let Ayyas failed to keep his faith. On one side, as a good Muslim, he had tried hard to do all the religious guidance obediently.

Those are the most important point that can be considered about Ayyas's personality. In that story, he is described and portrayed as knowledgeable, well-educated man, mentally agile, as well as influential. Although he always came across Linor and started finding her indignity and a loss of respect to Islam, he still had to show his respect. Never did he show a bad respect to Linor. Islam was always blustered and derailed wrongly by Linor. During living in Moscow, Linor was the girl who most often belittled wrongly about Ayyas's faith. This is the quotation of her demeanor.

"Ternyata benar, banyak sekali penganut agama primitif itu." (El-Zirazy, 2013p. 96)

"Apa maksud Anda? Siapa yang Anda maksud penganut agama primitif"... (El-Zirazy, 2013, p. 96).

The above conversation shows the way Linor viewed Islam as well Ayyas. Islam was such a primitive religion and Linor apparently hated it. Therefore, the expression that was said by Linor while she met Ayyas at the first time in the living room of their apartment was the proof of her hate to Islam. On one side, hearing and realizing Linor's insult, Ayyas was still able to control himself although his brain was too heat by that saying. Eventually in the end of that sudden meeting, Ayyas could perfectly manage his mind and behavior. However, despite of the fact that he was hard to control his emotions toward Linor' attitude. It is the following quotation.

"Ia ingin memberikan pandangan yang berbeda dari yang selama ini diyakini gadis itu... (El-Zirazy, 2013, p. 103).

Ayyas never came late to do his worship. For five times a day, his knees are always on the floor to remember Allah. His principle in life is so strong hence he was disinterestedly to maintain the entirely Islam tenets. He always remembered Allah wherever and whenever he was. Reading $d z i k r$ and Al-Qur'an were always done by him to prove that he was truly surrendered himself to Allah. Since it is important to set the mind of Allah existence in life, one of the ways to remember his existence is by understanding his greatness and infiltrating his holy words stated in Al-Qur'an. Praising and commending with full of surrender will bring something different in heart and mind. This cogitation is in line to Al-Qur'an, Al Isra' (9) in which from that verses, people can use them as guidance in life because they are as the best of the best guideline for all Muslims.

Ayyas greatly believed on that verse truth, thus he always read Al-Qur'an and dzikir after his praying for five times a day. Seemingly, he also did not want to waste his time with useless activities. He tried hard to sharpen his knowledge by reading Mudzakarat fi Manazil AshShiddiqin in which from it he could understand the whole explanations of the shining sentences 


MIMESIS
Und. 2. No. 1, Januari 2021
Universitas
Ahmad Dahlan

from Ibnu Athaillah As Sakandary. He always improved his literacy by reading all the references. He strongly believed that reading Al-Qur'an and dzikir ma'tsurat could improve his soul and mind. That notion is strengthened by the following quotation.

"Selesai shalat Subuh, seperti biasa, ia membaca Al-Quran, zikir ma'tsurat pagi, ..." (El-Zirazy, 2013, p. 105).

Dengan melanggengkan zikir sebagai pembuka kegiatan harian ia berharap, Allah senantia menjaga jiwa, raga, akal, dan akhlaknya ... (El-Zirazy, 2013, p.105-106).

Furthermore, Ayyas also was patient and calm when facing some problems. As a human, it is impossible to be out of problems and obstacles. As a good Muslim, being patient and calm is the answer. Furthermore, since he had lived abroad or beyond Muslim surrounding, he found some different ways of life. Several seductions were in front of him. Living in Moscow with its different faith was much more severe. It is because the way of life and principles between, Muslim and non-Muslim are so different.

People are created as a social human being (Luthans and Youssef 2004; Burr 2006). Therefore, they must make some interactions with the other. During that on-going interaction or activities, there must be any miss-understanding, or some conflicts happened between them. In the story, Muhammad Ayyas showed how he gave a help to Yelena when she got an accident. He helped Yelena sincerely with no mainstream.

A good Muslim will be seen not only from his behavior but also from the way he acts with the other. Ayyas was able to make a good friend among cross religious members and that made him got many easy on doing all his tasks. Furthermore, knowing and realizing that his friends, Yelena and Linor were not a good person; he tried hard to give them advice. However, he was giving some wonderful suggestions with a polite manner. The background of Yelena's life and how Ayyas' response of that fact can be seen from the following quotation.

"Tidak. Dulu aku memang pernah memeluk suatu agama. Pernah Budha, pernah Konghucu, pernah Ortodoks, dan pernah Islam?"... (El-Zirazy, 2013, p. 89).

"Memang, untuk urusan agama dan soal ketuhanan, Ayyas tergolong sensitif... (El-Zirazy, 2013, p. 89).

Since, Ayyas was grown up in a good condition with Muslim family background; he could pass the problems carefully. Even, not only that, he could make Yelena and Linor started to change their minds about their life. He influenced people around him with respectfully and well mannered. For example, when Yelena showed her faith of God's existence, when she claimed that there is no God in this world, Ayyas was disappointed. He carefully explained to Yelena about the existence of God in this world. His communicative and sociable, particularly about religious finally can enlighten the two ladies; Yelena and Linor.

\section{The Portrayed Of Islam In Bumi Cinta}

To discuss about how Habiburrahman El-Shirazy portrayed Islam in the story, it cannot be separated from the understanding of Islam in a wider context. Galwash (1966, p. 114) briefly stated that for Islam is literary signifying to Allah' will therefore it should be comprehensively and commonly applied as what the Prophet Mohammad did. Not only embodying for the 


MIMESIS
Und. 2. No. 1, Januari 2021
Universitas
Ahmad Dahlan

worship to Allah, Islam also encompasses the duties of life. This is the proof that Islam also concerned on the various section of law. Furthermore, that section is then broken down into some parts such as beliefs, practical devotions, transactions, moralities, and punishment. In addition, Islam has been used for many times as the main theme for some film narratives in Indonesia (Izharuddin 2016, 2017; Sasono 2013).

Through the representation of the main character, Ayyas, Islam is portrayed by the author of Bumi Cinta either substantively or formality. The term substantive refers to the way how the character interpretive Islam as set of beliefs and values as well as moral arrangements (Arthur and Carr 2013). On the other hand, the term formalist refers to the way on how to apply the roles of Islam in the whole of life (Addison 2000; Khan 2000). At a glance, formalist Islam emphasizes on how to understand and interpretative Islam textually which is adversative with substantive Islam. Those two mainstreams are shown in some chapters of the novel. It is also shown on how the five sections of law in Islam are reflected in the story by the main characters particularly Ayyas.

Since novel is also a part of reflection of people at that time (Eales-Reynolds and Clarke 2012; Ward and Himes 2019), when Habiburrahman El-Shirazy created it, the values of Islam in Indonesia are appeared. Islam is a dominant religion among the other. Mostly Indonesian people knew about Islam and they admit that Islam is their religion. However, the way Indonesian people understand and manifest their beliefs about Islam are varying. Besides, it is fact that there are several differences in interpreting Islam. That is why, it makes Islam has a wide range variation of interpretations. As an addition, Nasr (2009) and Elias (1999, p.17) stated that it is approximately 1 billion adherents worldwide who admitted Islam as their religion. Muslim community also easily found, living in Asia, Africa, and Europe in the seventh century. Realizing the fact, Bumi Cinta as a religious and Islamic novel is also among other interpretations which are formed in the form of a printed story.

Furthermore, when discussing about Islam, it cannot be separated from the three things: (1) the duties or the responsibilities that should be set on Islamic teaching in general, (2) the manner that are associated with social human life, and (3) the qualities of each character. A good Muslim must have a good quality of character which based on Prophet Muhammad's character (Funke and Thinking 2017; Izfanna and Hisyam 2012). It is since the best person in the world was him, Prophet Muhammad. Moreover, it is because his behavior and his though reflected what had been taught by Al-Qur'an. What had been stated in Al-Qur'an such as the seven characteristics of being a good Muslim and that stated in surah Al-Mu'minun verse 23. They are those who deeply absorbed or humble themselves in their prayers, always kept at a distance or avoid vain talks, active in deeds of charity, abstain from sex, except with those joined to them in the marriage bond, or whom their right hands possess for they are free from blame, those who faithfully observe their trusts and their covenants, and those who strictly guard their prayers.

The delineation of Islam in the story of Bumi Cinta is quite fair. Islam is the way of life in which when believing this ideology, the performer or the Muslim will become a good one. What is reflected in the character of Ayyas is the same with the Muslim in real life. Islam is 


MIMESIS
Und. 2. No. 1, Januari 2021
Universitas
Ahmad Dahlan

not only set of daily habit in which its followers must obey all the religious requirements absolutely. However, Islam is a way of life that provides the entirely human' need to be used as tools in their life. The intention of evaluating and delineation to this novel which based on Islamic discourse is to reveal what is Islam in this story context. It is supported by the current issues about Islam that considered as an extreme religion.

The novel Bumi Cinta reflects Islam as a good way of life which supports its followers at a peacefulness. What has been described in the story of Bumi Cinta about Islam is a truly peaceful religion. It is as if, Muhammad Ayyas can be the example of a good Islam follower. Islam through the plot of the story and the characters' representation are totally based on the five points of Islam such as belief in Allah, his angels, his Al-Qur'an, his prophets, the day of resurrection, and predestinations. They are internalized and actualized by Muhammad Ayyas in his daily life thus it can be said that Islam is appealed as all the best man or insan. The main character of Ayyas showed his manner in their life. He also does his devotion such as recital of creed, prayer to god, praying legal alms, in which they can be used to capture about Islam in daily life. What has been stated above is in line with the following verse (8) stated in Surah Luqman.

The actions and behaviors of the main character was appropriate to the Al-Qur'an, such as being on time to do worship, to have well behaved, and to have a good morality. Furthermore, Muhammad Ayyas was also fair in behaving with his environment. What had been stated in surah An-Nahl verse 90 had reflected by him.

As Islam also teaches its followers or the members of Islam on how to behave with the other religious members carefully, thus there are several examples that are shown by Muhammad Ayyas dealing with the cases. Some of the examples are when he interacted with Yelena and Linor who are obviously ignored Islam. What had been done and reflected from his personality were almost the same with Islam' tenets. The following surah and verses are the basic guidelines such as An Nahl verse 125.

One of the ways to determine a famous novel is by its readers' responses. When several people are curious to read thus it can be judged that the novel is a good and popular. However, it is still needed to question whether the novel has good moral messages or not. The quality of its content will prevail when a content analysis will be done to investigate. Realizing that Islamic religious values are everything that derives from Al-Qur'an as Allah's tenets, thus in fact, what have been portrayed about Islam in the story of Bumi Cinta is quite reflected AlQur'an. Allah had already taught us through his holy Qur'an such as how to dive the world his guidance such as confess that only Allah as the greatest thing in this world, doing all the religious command, being passion, avoiding the haram foods, being fair in making friendship, and so forth.

Based on the result of data description, novel entitled Bumi Cinta is determined to be a good one. It is filled with some good moralities. Several religious values were served perfectly without hurting another religion. The presentation of Islam is a normal and natural. It is far from pleonastic images. The representation of the main character especially Muhammad Ayyas 


MIMESIS
Und. 2. No. 1, Januari 2021
Universitas
Ahmad Dahlan

is not overacting. On the other hand, the story is quite inspiring. It can enlighten people to be a good people like what the main character does.

The findings of this study actually challenges what Plato said that it confused to reveal the study of 'aesthetics' with the study of 'morals' (Literary Criticism and Theories, 2012). From the tenet proposed by Plato, it can be understood that there is a distance between the work of literature and morality. On the other hand, from this novel, some good characters can be exposed. To emphasize, the characterization of Ayyas is the ideal of Muslim. His personality and his behavior are referring to what has been stated in Al-Qur'an as the absolute fact. It is because when those absolute facts become the single greatest sign of God in the physical, thus it leaves no doubt for many Muslims. It is likewise what Ayyas did in his live during living in Russia. One of the best examples that was shown by him are that he seriously keeps avoiding talking with the other women who do not have a relative relationship with him as well as keeps avoiding eating haram food. Deal with this, Allah has already taught us in Al-Quran that a good Muslim must aware of the entirely good food. It is obviously stated in An-Nahl verse 114.

The existence of Ayyas in the story has given the model on how to be a perfect Muslim. The simplest thing until the complex one in religious context has been portrayed perfectly and logically. This humanist novel of Bumi Cinta can never be avoided for its existence. Furthermore, this novel is also heart-warming. Its universal values must be able to dig out the readers' feelings and emotions. Readers can get much information about Islam. They will also get a quite clear of Islam in a daily of life. Rules and dynamics in Islam can be understood easily.

However, the most important point that should be emphasized from the story of the novel is that Islam is such an ideology that formed into set of rules, duties, and responsibilities in which are directly derived from the Qur'an and Hadist. Thus, those are reflected by the main characters perfectly. There aren't any miss perception and interpretation about those verses through the representation of Muhammad Ayyas. Through the story of Bumi Cinta, all the aspects of life have been performed in a highly tranquility level. Therefore, this finding is in line to what Papanicolopulu (2018), Din (2016), and Ikhwan (2016) have done in their researches.

Based on Bumi Cinta story, the values of Islamic religious are acclaimed that Islam is a way of life. It is not only a set of ritualistic but also an ideology in which its power can control the characters of the story behavior and mindset. As an ideology, based on the story, Islam also powerfully converts the values and laws that are believed, and it can be used to control the human' life. Muhammad Ayyas, Yelena, and Linor are the example on how they believed in Islam and applied that set of tenets in their life. When they believed that Islam is their ideology, it meant that Islam will encompass some basic of ideas, concept, thought, in which they can born a system or rules that are used as the references for them in undergoing their life.

It can be said that Islam based on the story representation is enlightenment, peaceful and tolerance. There are not any threatening, terror, fanaticism, hatred, rough, and tumble instead of the coming Muslim in the society can inspire the people around to be calm and 


MIMESIS
VoL. 2. No. 1, Januari 2021
Universitas
Ahmad Dahlan

comfortable. The more highly behavior possessed by Muslims, the more people outside Islam show their respect and sympathy and this has been appeared from Bumi Cinta. Some good values represented within Bumi Cinta by the main character are expected to stimulate readers to have a good character. The readers who previously considered Islam is a religious terrorist can change their mind.

In addition, having read this story, readers can also get some abstractions from the example given by the main characters. Take for example how Ayyas behaved when facing the problem. This part is considered important because one of the most significant aspects of the story is its conflict (Baker 2018; Kristof and Ortega 2019). The conflict or the problem which is happened in Bumi Cinta relates to the social and religious dynamics. Other than that, the main character, Muhammad Ayyas is also exposed to control his emotion and personality when facing with some controversial youngster lifestyles. Islamic values are beautifully represented and are portrayed as if in the real-life context. Those conflicts happen in the novel Bumi Cinta can be used as a lesson or moral teaching. This idea is supported by some previous studies that from the literary artwork, moral values can be inculcated (Anindyarini et al. 2017; Feldstern and Ryan 2019; Koh and Ummi 2014; Rahutami 2017).

Having analyzed this novel, Islamic readers are expected to be aware and awake of the harmonist existence in this life. They are supposed to have the ability in reducing the kind of conflicts. This issue is very crucial to consider because today various types of conflicts that occur in the world are increasing and causing various pain and anxiety. There are many factors that affect those kind of conflicts such as religion, ethnicity, and economic level of differences issues (Magaldi, Conway, and Trub 2018; Wang 2018). However, among the factors stimulating conflicts, religion issue is mostly and frequently reported in the mass media and becomes one of the most catastrophic arousing disputes (Deutsch, Coleman, and Marcus 2011).

Furthermore, religious dispute is often assumed to be one of the most causing national disharmonious and instability (Mitchell 1989; Moffitt and Bordone 2012). There are many states that their national stability was threatening caused by civil war stimulated by religion disputes. Whether it is true or not and whatever the reason, chronicle dispute can create war which had a catastrophic effect on human and aspect of life. Take for example, A number of destroying communities and families, disrupting social and economic development, affecting long-term physical and psychological harm to children, and reducing material and human capital are the explicit causes of conflict (Murthy and Lakshminarayana 2006).

Therefore, having get a great understanding from this novel, people who are outside Islam will have new information what is Islam actually. In addition, Muslim who has wrong interpretation of Islamic values can change their mind and start to reduce the conflict stimulation. These issues must be kept in mind because in our reality, dealing with the religiosity, some believe that points of the conflicts are alerted by the fanaticism (Michael 2018; Torty 2009). This is caused by the direct impact of the way people see and believe their ideology. Recently, several conflicts that the impacts are pursuing public to cautioning Islam increase. The conflicts and the disturbances which are branded with Islam make the global 


MIMESIS
Und. 2. No. 1, Januari 2021
Universitas
Ahmad Dahlan

public see and consider Islam is a terrorist religion. Consequently, it is a must for the Muslim to show and to give the evidence that Islam is like to what Bumi Cinta says about Islam.

\section{CONCLUSION}

The three characters have different roles in the story. Ayyas is the main character who is categorized as the flat character because he is set as a good people starting from the beginning of the story until the end of it. He is also set as a good man who tries hard to maintain his principles in Islam. On the other hand, Yelena who is also the main character of the story is categorized as the round one whose personality changes. She is described as an atheist but finally set her mind and live in Islam. In line with the characterization and the plot of Yelena's life, Linor as her apartment mate also finds her equanimity in Islam.

There are some fundamental points from this finding which can inspire readers to do and to be a good Muslim. They are: a) how to strive science and knowledge, b) being discipline in doing the worship, c) avoiding the religious prohibitions and performing the religious obligation, d) always remembering to Allah wherever and whenever we are, e) patient and calm when facing some problems, f) patient and calm when facing some seductions, g) sincerely when serving the helps to others, h) making good friends among cross religious members, i) giving good advice with polite manners, and j) supporting and appealing to be a good person. Those religious values are explicitly described in the entirely story whereas, the representation of Islam through the story is that enlightenment, peaceful and tolerance. There are not any threatening, terror, fanaticism, hatred, rough, and tumble within Islam.

This finding of the study showed that Islam is a good and right religion. Through the representation of some main characters, there is no harm in Islam. Islam is nicely and wisely described by the novel author. From having a good understanding on Islam, new and great cavillation can be established.

\section{REFERENCES}

Addison, Nicholas. 2000. "10.1 The Function of Critical and Contextual Studies." Learning to Teach Art \& Design in The Secondary School: A Companion to School Experience, 240.

Sardjijo A. 2017. "Character Education Through Good Harmony Activities in School." The International Journal of Social Sciences and Humanities Invention.

Anindyarini, Atikah, Fathur Rokhman, Mimi Mulyani, and Others. 2017. "Moral Value or Character in Fantasy Story." In International Conference On Teacher Training And Education 2017 (ICTTE 2017). Atlantis Press.

Arthur, James, And David Carr. 2013. "Character in Learning for Life: A Virtue-Ethical Rationale for Recent Research on Moral and Values Education.” Journal of Beliefs \& Values. 
Baker, Mona. 2018. Translation And Conflict: A Narrative Account. Routledge. Https://Market.Android.Com/Details?Id=Book-M_L0dwaaqbaj.

Bennett, Andrew. 2014. "An Introduction To Literature, Criticism And Theory." Https://Doi.Org/10.4324/9781315834252.

Blackburn, Steven. 2007. "Islamic Philosophy from Its Origin to The Present: Philosophy in The Land of Prophecy? By Seyyed Hossein Nasr." Reviews in Religion \& Theology.

Booth, Wayne C. 2010. The Rhetoric of Fiction. University of Chicago Press.

Burr, V. 2006. "An Introduction to Social Constructionism." Https://Content.Taylorfrancis.Com/Books/Download.

Chandler, Daniel. 2007. "Semiotics the Basics Second Edition". Oxon: Routledge.

Dallas, B. C. 2000. "Play, Photoplay, And Screenplay Structure: Dramatic Principles From Theater To Cinema.” Http://Scholarworks.Sjsu.Edu/

Deutsch, Morton, Peter T. Coleman, And Eric C. Marcus. 2011. The Handbook Of Conflict Resolution: Theory And Practice. John Wiley \& Sons.

Din, Mehraj Ud. 2016. "Confronting Political Islam: Six Lessons From The West's Past." Politics, Religion \& Ideology. Https://Doi.Org/10.1080/21567689.2016.1159844.

Eagleton, Terry. 2013. The English Novel: An Introduction. John Wiley \& Sons. Https://Market.Android.Com/Details.

Elias, Jamal J. Islam Religion of The World. New Fetter Lane, London: Routledge, 1999.

Eales-Reynolds, Lesley-Jane, And Colin Clarke. 2012. "Impact of A Novel Training Experience on The Development of a Customer Service Culture in A Large Hospital Trust." International Journal of Health Care Quality Assurance 25 (6): 483-97.

Elmer, Jonathan, Bobby L. Jones, Vladimir I. Zadorozhny, Juan Carlos Puyana, Kate L. Flickinger, Clifton W. Callaway, And Daniel Nagin. 2019. “A Novel Methodological Framework for Multimodality, Trajectory Model-Based Prognostication." Resuscitation 137 (April): 197-204.

Falniowski, A., And M. Szarowska. 2009. "Can Poorly Understood New Characters Support A Poorly Understood Phylogeny? Shell-Structure Data in Hydrobiid Systematics (Mollusca: Gastropoda: Prosobranchia: Hydrobiidae)." Journal of Zoological Systematics and Evolutionary Research.

Feldstern, Liz, And Amanda Ryan. 2019. "Teaching The Lesson Of Moral Courage Through Writing." Unlikely Heroes. Https://Doi.Org/10.2307/J.Ctvd58t29.12.

Fenton, Adam J. 2016. "Faith, Intolerance, Violence and Bigotry: Legal And Constitutional Issues of Freedom of Religion In Indonesia.” Journal of Indonesian Islam.

Foster, Steve. 2016. "11. Freedom of Religion, Association, And Peaceful Assembly." Law Trove. Https://Doi.Org/10.1093/He/9780198745174.003.0011.

Funke, Joachim, And Latest Thinking. 2017. "Which Character Traits Are Important For Good Decision-Making?” Latest Thinking. Https://Doi.Org/10.21036/Ltpub10567.

Galwash, Ahmad. 1966. The Religion Of Islam: A Standard Book. Vol. 12. Supreme Council for Islamic Affairs. 


MIMESIS
Und. 2. No. 1, Januari 2021
Universitas
Ahmad Dahlan

Green, Melanie C. 2004. "Transportation into Narrative Worlds: The Role of Prior Knowledge and Perceived Realism." Discourse Processes 38 (2): 247-66.

Habegger-Conti, Jena. 2017. “'On With The Story!' John Barth's Theory of Narrative Digression." Textual Wanderings. Https://Doi.Org/10.4324/9781351192996-4.

Hakim, Lukman. "Conservative Islam Turn or Popular Islam? An Analysis of The Film AyatAyat Cinta." Al-Jami'ah Journal of Islamic Studies, 2010: 101-128.

Hassan, Ummu Hani Abu, And Koh Young Hun. 2018. "A Comparison of The Concept of Romantic Love in The Novels Ayat-Ayat Cinta 2 And Salju Sakinah." Malay Literature 31 (1): 98-123.

Halstead, J. Mark. "Islamic Values: A Distinctive Framework for Moral Education?" Journal of Moral Education, Vol. 36, No. 3, September 2007, Pp. 283-296.

Ikhwan, Afiful. 2016. "Leadership In Islamic Education: Study Of Thematic Al-Qur'an And Al-Hadist.” Ulul Albab Jurnal Studi Islam. Https://Doi.Org/10.18860/Ua.V17i1.3253. Izfanna, Duna, And Nik Ahmad Hisyam. 2012. "A Comprehensive Approach in Developing Akhlaq: A Case Study on The Implementation Of Character Education At Pondok Pesantren Darunnajah.” Multicultural Education \& Technology Journal 6 (2): 77-86.

Izharuddin, Alicia. 2016. Gender And Islam In Indonesian Cinema. Springer. Https://Market.Android.Com/Details?Id=Book-U1todqaaqbaj.

. 2017. "Dakwah At The Cinema: Identifying The Generic Parameters Of Islamic Films." Gender And Islam In Indonesian Cinema. Https:/Doi.Org/10.1007/978-98110-2173-2_2.

Jazeera, A1. 2019. "New Zealand Mosque Attack: Who Were The Victims?" Al Jazeera. Accessed July 5, 2019. Https://www.Aljazeera.Com/ 9297.

Johns, Christopher. 2011. Guided Reflection: A Narrative Approach To Advancing Professional Practice. John Wiley \& Sons.

Khan, Sayyid Ahmad. 2000. "The Way of Life." Modernist and Fundamentalist Debates in Islam.

Koh, Younghun, And Ummi Hani Binti. 2014. "The Rhetorics Strateges In The Novel Bumi Cinta By Habiburrahman El-Shirazy."

Krippendorff, Klaus. 2018. Content Analysis: An Introduction To Its Methodology. SAGE Publications.

Kristof, Arnold S., And Victor E. Ortega. 2019. "The Discovery of Novel Mechanisms For Lymphangioleiomyomatosis Pathogenesis Through GWAS: A Rarity In Rare Respiratory Disorders." The European Respiratory Journal: Official Journal Of The European Society For Clinical Respiratory Physiology 53 (6).

Lortie, F. 1999. "Healing Dramas and Clinical Plots: The Narrative Structure Of Experience." BMJ 318 (7192): 1219.

Luthans, Fred, and Carolyn M. Youssef. 2004. "Human, Social, And Now Positive Psychological Capital Management: Investing in People for Competitive Advantage," Management Department Faculty Publications. 


MIMESIS
Und. 2. No. 1, Januari 2021
Universitas
Ahmad Dahlan

Magaldi, Danielle, Timothy Conway, And Leora Trub. 2018. “I Am Here for A Reason': Minority Teachers Bridging Many Divides in Urban Education.” Race Ethnicity and Education.

Mar, Raymond A., And Keith Oatley. 2008. "The Function of Fiction Is the Abstraction and Simulation of Social Experience." Perspectives on Psychological Science: A Journal of The Association for Psychological Science 3 (3): 173-92.

Meer, Nasar, And Tariq Modood. 2009. "Refutations of Racism in the 'Muslim Question."” Patterns of Prejudice 43 (3-4): 335-54.

Michael, Chiangi. 2018. "The Complex Dynamics of Religious Conflicts and The Boko Haram Sectarian Crisis in Nigeria."

Mitchell, C. R. 1989. The Structure of International Conflict. Springer.

Moffitt, Michael L., And Robert C. Bordone. 2012. The Handbook Of Dispute Resolution. John Wiley \& Sons.

Mubin, Minahul. 2014. "Religiusitas Tokoh-Tokoh Dalam Novel Bumi Cinta Karya Habiburrahman El-Shirazy.” AKADEMIKA.

Murthy, R. Srinivasa, And Rashmi Lakshminarayana. 2006. "Mental Health Consequences of War: A Brief Review Of Research Findings." World Psychiatry: Official Journal of The World Psychiatric Association 5 (1): 25-30.

Muslim. 2017. Hadits Shahih Bukhari - Muslim (Hc). Elex Media Komputindo.

Nasr, Seyyed Hossein. 2009. The Heart of Islam: Enduring Values For Humanity. Zondervan.

Nasr, Seyyed Hossein. ISLAM: Religion, History, And Civilization. New York: Harpercollins E-Books, 2007.

Papanicolopulu, Irini. 2018. "From Set of Rules to Legal Regime." Oxford Scholarship Online.

Rahutami, And Rahutami Rahutami. 2017. "The Construction of Ideology Through Syntactic Strategy In The Novel Bumi Manusia.” The Tenth Conference On Applied Linguistics And The Second English Language Teaching and Technology Conference.

Sasono, Eric. 2013. "Islamic Revivalism and Religious Piety in Indonesian Cinema." In Performance, Popular Culture, And Piety In Muslim Southeast Asia, Edited By Timothy P. Daniels, 45-75. New York: Palgrave Macmillan US.

S. Moschtaghi Ramin. 2012. "Part 5 Emerging Constitutions in Islamic Countries, 5.10 Constitutionalism in An Islamic Republic: The Principles of The Afghan Constitution and The Conflicts Between Them." Constitutionalism in Islamic Countries: Between Upheaval and Continuity.

Shomiyatun. Metode Penanaman Nilai-Nilai Agama Moral Dan Budi Pekerti. Yogyakarta:

Sekolah Tinggi Pendidikan Islam Bina Insan Mulia Yogyakarta, 2010.

Suryaningsih, Iin. 2018. "The Value of Islamic Pedagogy and Arabic Science; The Study of Humanism In Manuscript of The Archipelago Figures Work." Prosiding Pertemuan Ilmiah Internasional Bahasa Arab 0 (0). 
Thomas, Jeffrey L. 2015. Scapegoating Islam: Intolerance, Security, And the American Muslim: Intolerance, Security, And the American Muslim. ABC-CLIO.

Toolan, M. 2012. "Narrative: A Critical Linguistic Introduction." Https:/Content.Taylorfrancis.Com/Books/

Torty, Livinus. 2009. “The Impact of Transnational Conflicts on Christian-Muslim Relations in Nigeria (2001-2006)."

Umer Chapra, M. 2016. The Future of Economics: An Islamic Perspective. Kube Publishing Ltd.

Valk, John, And Mualla Selçuk. 2017. "Journeying into A Peaceful Islam: A Worldview Framework Approach." Religion and Violence.

Wang, Tao. 2018. "Religion-Based Cultural Identity and Conflicts of Migrant Muslim Students in Northwest China." Race Ethnicity and Education.

Ward, Kate, And Kenneth Himes. 2019. Growing Apart: Religious Reflection on The Rise of Economic Inequality. MDPI.

Zainiyati, Husniyatus Salamah. 2016. "Curriculum, Islamic Understanding and Radical Islamic Movements in Indonesia." Journal of Indonesian Islam 